\section{Effects of Pressure Overload, Left Ventricular Hypertrophy on $\beta$-Adrenergic Receptors, and Responsiveness to Catecholamines}

Dorothy E. Vatner, Charles J. Homcy, Siu Po Sit, W. Thomas Manders, and Stephen F. Vatner Departments of Medicine, Harvard Medical School, Massachusetts General Hospital, and Brigham \& Women's Hospital, Boston, Massachusetts 02114; Department of Cellular \& Molecular Research, Massachusetts General Hospital, and the New England Regional Primate Research Center, Southboro, Massachusetts 01772 bstract. Pressure overload left ventricular (LV) hypertrophy was produced by banding the ascending aorta of puppies and allowing them to grow to adulthood. LV free wall weight per body weight increased by $87 \%$ from a normal value of $3.23 \pm 0.19 \mathrm{~g} / \mathrm{kg}$. Hemodynamic studies of conscious dogs with LV hypertrophy and of normal, conscious dogs without LV hypertrophy showed similar base-line values for mean arterial pressure, heart rate, and LV end-diastolic pressure and diameter. LV systolic pressure was significantly greater, $P<0.01$, and LV stroke shortening was significantly less, $P<0.01$, in the LV hypertrophy group. In both normal and LV hypertrophy groups, increasing bolus doses of norepinephrine or isoproterenol produced equivalent changes in LV dP/dt.

$\beta$-adrenergic receptor binding studies with $\left[{ }^{3} \mathrm{H}\right]$ dihydroalprenolol $\left.\left({ }^{3} \mathrm{H}\right] \mathrm{DHA}\right)$ indicated that the density of binding sites was significantly elevated, $P<0.01$, in the hypertrophied LV plasma membranes $(111 \pm 8.8$, $n=8)$, as compared with normal LV $(61 \pm 5.6 \mathrm{fmol} / \mathrm{mg}$ protein, $n=11)$. The receptor affinity decreased, i.e.,

Dr. Dorothy Vatner was supported by a U. S. Public Health Service Fellowship (No. 5 F32 HL06183) and is currently supported by a New Investigator Research Award (No. HL31280). Dr. Homcy is an Established Investigator of the American Heart Association. Address correspondence to Dr. Stephen Vatner, New England Regional Primate Center, and address reprint requests to Dr. Dorothy Vatner, Department of Cellular \& Molecular Research, Massachusetts General Hospital. 1984.

Received for publication 25 May 1983 and in revised form 4 January

J. Clin. Invest.

(c) The American Society for Clinical Investigation, Inc.

$0021-9738 / 84 / 05 / 1473 / 10 \$ 1.00$

Volume 73, May 1984, 1473-1482 disassociation constant $\left(K_{\mathrm{D}}\right)$ increased, selectively in the $\mathrm{LV}$ of the hypertrophy group; the $K_{\mathrm{D}}$ in the normal LV was $6.8 \pm 0.7 \mathrm{nM}$ compared with $10.7 \pm 1.8 \mathrm{nM}$ in the hypertrophied LV. These effects were observed only in the LV of the LV hypertrophy group and not in the right ventricles from the same dogs. The plasma membrane marker, $5^{\prime}$-nucleotidase activity, was slightly lower per milligram protein in the LV hypertrophy group, indicating that the differences in $\beta$-adrenergic receptor binding and affinity were not due to an increase in plasma membrane protein in the LV hypertrophy group. $\mathrm{The}^{\mathrm{EC}} \mathrm{C}_{50}$ for isoproterenol-stimulated adenylate cyclase activity was similar in both the right and left ventricles and in the two groups. However, maximal-stimulated adenylate cyclase was lower in the hypertrophied left ventricle. Plasma catecholamines were similar in the normal and hypertrophied groups, but myocardial norepinephrine was depressed in the dogs with LV hypertrophy $(163 \pm 48 \mathrm{pg} / \mathrm{mg}$ ) compared with normal dogs $(835 \pm 166 \mathrm{pg} / \mathrm{mg})$.

Thus, severe, but compensated LV hypertrophy, induced by aortic banding in puppies, is characterized by essentially normal hemodynamics in adult dogs studied at rest and in response to catecholamines in the conscious state. At the cellular level, reduced affinity and increased $\beta$-adrenergic receptor number characterized the LV hypertrophy group, while the $\mathrm{EC}_{50}$ for isoproterenol-stimulated adenylate cyclase activity was normal. By these mechanisms, adequate responsiveness to catecholamines is retained in conscious dogs with severe LV hypertrophy.

\section{Introduction}

Hypertrophy is a major mechanism by which the left ventricle compensates to a chronic pressure overload. The sympathetic 
nervous system is another major compensatory mechanism, and is recruited in response to stress. It is conceivable that $\beta$ adrenergic mechanisms of the heart are responsible in part for the preservation of mechanical function in the presence of hypertrophy, and alterations in autonomic control may be involved in the process of decompensation associated with the development of cardiac failure.

The goal of the present investigation was to characterize $\beta$ adrenergic regulation of the severely hypertrophied left ventricle, which is induced by chronic, severe pressure overload. These studies were designed to examine inotropic responsiveness to catecholamines in the intact, conscious animal with left ventricular (LV) ${ }^{1}$ hypertrophy, and then to investigate the extent to which the biochemical determinations could explain the physiological responses. The biochemical analyses initially were directed towards investigation of $\beta$-adrenergic receptor number and affinity, and progressed to the study of coupling of $\beta$-adrenergic receptors to adenylate cyclase. Finally, catecholamines were measured in the hypertrophied left ventricle and in the plasma of these dogs, and compared with values obtained in the normal animals.

\section{Methods}

Preparation of model. Mongrel puppies of either sex at 7-10 wk of age were anesthetized with halothane ( 1 vol per $100 \mathrm{ml}$ ), ventilated with a respirator, and a right thoracotomy was performed through the fifth intercostal space. The ascending aorta above the coronary arteries was isolated and dissected free of surrounding tissue. In the puppies designated as sham controls, the chests were closed at this time. In the group designated for $\mathrm{LV}$ hypertrophy, a Teflon cuff (6-8 $\mathrm{mm}$ in diameter) was placed around the aorta and the chest was closed. Both groups of puppies were then allowed to recover and grow for 10-16 mo to adulthood before experimentation. The cuff produced a fixed lesion. $60 \%$ of the puppies survived the initial 10-16-mo period after aortic banding.

Instrumentation of animals. At operation, six adult dogs with LV hypertrophy, three sham operated dogs, and three normal, mongrel dogs were sedated with propriopromazine $\mathrm{HCl}$ (Tranvet; Diamond Laboratories, Inc., Des Moines, IO) and anesthetized with sodium pentobarbital $(30 \mathrm{mg} / \mathrm{kg}$, i.v.). Using sterile technique and through an incision in the left fifth intercostal space, Tygon (Norton Co., Plastics and Synthetic Div. Akron, $\mathrm{OH}$ ) catheters were implanted in the descending thoracic aorta and left atrium, piezoelectric transducers were implanted on opposing anterior and posterior endocardial surfaces of the left ventricle, and a solid state pressure gauge (P 22, Konigsberg Instruments, Inc., Pasadena, CA) was inserted into the left ventricle via an apical stab wound. The incision then was closed in layers, the pneumothorax reduced, and the animals were allowed to recover.

Arterial and left atrial pressures were measured using the implanted catheters and Statham P23Db strain gauge manometers (Statham Instruments, Inc., Oxnard, CA). LV pressure was measured with the solid state miniature pressure gauge and calibrated in vitro against a mercury manometer and in vivo against the arterial and left atrial pressure mea-

1. Abbreviations used in this paper: $\left[{ }^{3} \mathrm{H}\right] \mathrm{DHA}$, dihydroalprenolol; LV, left ventricular; $R V$, right ventricular. surements. An improved ultrasonic transit-time dimension gauge $(1,2)$ was used to measure $L V$ diameter. The instrument generates a voltage linearly proportional to the transit time of acoustic impulses traveling at the sonic velocity of $1.5 \times 10^{6} \mathrm{~mm} / \mathrm{s}$ between the $3 \mathrm{MHz}$ piezoelectric crystals, thus giving a record of instantaneous $\mathrm{LV}$ diameter. The frequency response of the dimension gauge is flat to $60 \mathrm{~Hz}$. At a constant room temperature, the thermal drift of the instrument is minimal, i.e., $<0.01$ $\mathrm{mm}$ in $6 \mathrm{~h}$. Any drift in the measurement system was eliminated during the experiment by periodic calibrations. This involved substituting pulses of known duration from a crystal-controlled pulse generator with a stability of $0.001 \%$. The position of all transducers was confirmed at autopsy.

The cardiac responses of conscious animals to exogenously administered norepinephrine and isoproterenol were examined in six dogs with LV hypertrophy and in six normal dogs, of which three were sham operated controls. Norepinephrine was administered in bolus doses of $0.05,0.1,0.5,1.0$, and $1.5 \mu \mathrm{g} / \mathrm{kg}$, while isoproterenol was administered in bolus doses of $0.01,0.05,0.10$, and $0.50 \mu \mathrm{g} / \mathrm{kg}$. Bolus injections were administered in one 12-h period. Care was taken to allow full recovery of LV function before the next dose was administered. Reproducibility was assured by administering the same doses on a different day at least 3-7 d later.

The data were recorded on a multichannel tape recorder (Hewlett Packard Co., Palo Alto, CA) and played back on a direct writing oscillograph (Gould-Brush). A cardio-tachometer (Beckman No. 9857B Beckman Instruments, Inc., Fullerton, CA) triggered by the pressure pulse provided instantaneous and continuous records of heart rate. Continuous records of $L V \mathrm{dP} / \mathrm{dt}$ were derived from $\mathrm{LV}$ pressure signals using Philbrick operational amplifiers (Teledyne Philbrick, Dedham, MA), operated as differentiators, with a frequency response of $700 \mathrm{~Hz}$. A triangular wave signal was substituted for the pressure signal to calibrate the differentiators directly.

Biochemical studies. These studies were conducted at least $2 \mathrm{~d}$ and not $>1$ wk after the bolus doses of isoproterenol and norepinephrine. These studies were also carried out in five normal dogs and in two dogs with LV hypertrophy that were neither instrumented nor used for the experiments with sympathomimetic amines. After the dogs were anesthetized with $30 \mathrm{mg} / \mathrm{kg}$ sodium pentobarbital, the hearts were immediately excised and placed into iced Krebs-Ringer's solution. All subsequent procedures were carried out at $4^{\circ} \mathrm{C}$. Approximately $1 \mathrm{~mm}$ of epicardium and endocardium were removed with a scissors and discarded. LV myocardium was minced coarsely in buffer (sucrose $0.25 \mathrm{M}, \mathrm{MgCl}_{2} 1 \mathrm{mM}$, and $\mathrm{KHCO}_{3} 1 \mathrm{mM}$ ), and homogenized with a PT-10ST Polytron (Brinkmann Instruments, Inc., Westbury, NY) tissue disruptor. The homogenate was filtered through one layer of Japanese silk screen, size 12, and centrifuged in a Sorvall RC-2 (DuPont Instruments, DuPont Co., Wilmington, DE) at $1,000 \mathrm{~g}$ for $15 \mathrm{~min}$. The supernatant was respun at $18,000 \mathrm{~g}$ for $15 \mathrm{~min}$ and the pellet was resuspended in buffer (Tris 0.1 $\mathrm{M}, \mathrm{MgCl}_{2} 5 \mathrm{mM}$, and EDTA $1 \mathrm{mM}$ ), using a Teflon pestle in a PotterElvehjem homogenizer. The homogenization and $28,000 \mathrm{~g}$ spin were repeated twice. The pellet was resuspended to a protein concentration of $3 \mathrm{mg} / \mathrm{ml}$ and stored at $-70^{\circ} \mathrm{C}$ until assayed. At the time of assay, the membranes were again washed in the Tris buffer and centrifuged.

All studies were performed in triplicate in the presence of Tris 0.1 $\mathrm{M}, \mathrm{MgCl}_{2} 5 \mathrm{mM}$, and EDTA $1 \mathrm{mM}, \mathrm{pH}$ 7.2. For the determination of $\beta$-adrenergic receptor binding saturation, $100 \mu \mathrm{l}$ of the cardiac membrane preparation (2-3 mg protein per milliliter) was incubated at $37^{\circ} \mathrm{C}$ for $30 \mathrm{~min}$ with increasing concentrations $(1.0-50 \mathrm{nM})$ of $\left[{ }^{3} \mathrm{H}\right](-)$ dihydroalprenolol ( $\left.\left[{ }^{3} \mathrm{H}\right] \mathrm{DHA}\right)$ (New England Nuclear, Boston, MA), with or without unlabeled $d, l$-propranolol $(10 \mu \mathrm{M})$, in a final reaction volume 
of $150 \mu \mathrm{l}$. A concentration of $10 \mu \mathrm{M}$ propranolol was required to displace the ligand at the higher concentration of $\left[{ }^{3} \mathrm{H}\right] \mathrm{DHA}$. After incubation, the $150 \mu \mathrm{l}$ of reaction mixture was rapidly filtered under vacuum onto Whatman GF/C glass fiber filters (Whatman Laboratory Products, Inc., Clifton, N. J.). The filters were quickly washed $(<10 \mathrm{~s})$ three times with $4 \mathrm{ml} \mathrm{Tris-} \mathrm{MgCl}_{2}$-EDTA buffer, at $4^{\circ} \mathrm{C}$. The filters were counted for 10 $\mathrm{min}$ in $10 \mathrm{ml}$ of Hydrofluor (New England Nuclear) in a Packard Tricarb 300 scintillation counter (Hewlett Packard Co.) with a counting efficiency of $50 \%$. Isoproterenol competition curves were performed in triplicate with $100 \mu \mathrm{l}$ of the membrane preparation (2-3 mg protein per milliliter), $25 \mu \mathrm{l}$ of $\left[{ }^{3} \mathrm{H}\right] \mathrm{DHA} 10 \mathrm{nM}$, and $25 \mu \mathrm{l}$ of isoproterenol $\left(10^{-8}-10^{-3} \mathrm{M}\right)$. The incubation, filtering, and counting were performed as above for the Scatchard analysis.

For the adenylate cyclase assay, $50 \mu$ l of solution containing $1 \mathrm{mM}$ ATP $\left(2-3 \times 10^{6} \mathrm{cpm}\right.$ of $\left.\left.{ }^{32} \mathrm{P}\right] \mathrm{ATP}\right), 20 \mathrm{mM}$ creatine phosphate, $1 \mathrm{U}$ creatine phosphokinase, $1 \mathrm{mM}$ cyclic AMP $\left(2,000-3,000 \mathrm{cpm}\right.$ of ${ }^{3} \mathrm{H}$ cyclic AMP), $25 \mathrm{mM}$ Tris, $5 \mathrm{mM} \mathrm{MgCl}, 1 \mathrm{mM}$ EDTA, and the test substance, i.e., $10 \mathrm{mM}$ isoproterenol, $1.0 \mathrm{mM} \mathrm{GTP}$, and cardiac membranes containing 200-300 $\mu \mathrm{g}$ of protein, were incubated for $10 \mathrm{~min}$ in a shaking water bath at $37^{\circ} \mathrm{C}(3) .100 \mu \mathrm{l}$ of a stopping solution (20 mM ATP, $10 \mathrm{mM}$ cyclic AMP, and $2 \%$ sodium dodecyl sulfate) was added to each tube to terminate the reaction, and the tube was heated on a dry bath at $100^{\circ} \mathrm{C}$ for $3 \mathrm{~min} .0 .9 \mathrm{ml}$ of water was added and the mixture $(1.0 \mathrm{ml})$ was passed over a column of packed Dowex AG50 W-X4, 200-400 mesh, hydrogen form. The column was eluted with 2 $\mathrm{ml}$ of water, and then stacked on top of a 6-mm diameter column containing $1.2 \mathrm{~g}$ of alumina (Brockman Grade I) so that the eluate of one column ran onto the other. The Dowex column was eluted with 3 $\mathrm{ml}$ of water, and the eluent flowed onto the alumina column. The alumina column was then eluted with $3 \mathrm{ml}$ of $50 \mathrm{mM}$ imidazole, $\mathrm{pH}$ 7.4, directly into counting vials containing Hydrofluor (New England Nuclear) $(10 \mathrm{ml})$, and was counted in a Packard TriCarb 300 scintillation counter (Hewlett Packard Co.). Recovery of added cyclic AMP was 40$80 \%$. Zero time controls approached background. Maximal adenylate cyclase activity was assessed by measuring cyclic AMP production in the presence of either $10 \mathrm{mM} \mathrm{NaF}, 0.1 \mathrm{mM}$ GppNHp.

$5^{\prime}$ Nucleotidase (5'ribonucleotide phosphohydrolase) was assayed by the enzyme kinetic method of Arkesteijn (4). The rate of NAD formation from coupled reactions involving AMP and 2-oxoglutarate is measured by the decrease in absorbance at $340 \mu \mathrm{m}$, which is directly proportional to $5^{\prime}$-nucleotidase activity.

Plasma epinephrine, norepinephrine, and tissue norepinephrine levels were determined according to the method of DaPrada and Zurcher (5).

The protein concentrations for each membrane assay were determined by the Lowry method (6). Analysis of saturation binding assays was performed according to the method of Scatchard (7). The data were then analyzed with the iterative curve-fitting program "Ligand" of Munson and Rodbard (8).

Statistical analysis. Data were expressed as mean value \pm SEM. Data were stored in a digital computer (PDP-11/34) and statistical evaluation was performed by a one-way analysis of variance for linear contrasts and a multiple-way analysis of variance to determine significance between groups. Significance was determined using Scheffe's test (9).

\section{Results}

In the LV hypertrophy group, LV free wall weight per body weight $(6.03 \pm 0.36 \mathrm{~g} / \mathrm{kg})$ was almost twice that observed in the normal control group $(3.23 \pm 0.19 \mathrm{~g} / \mathrm{kg})$. Right ventricular (RV) free wall weight per body weight was only slightly elevated (Table
Table I. Morphology

\begin{tabular}{lccl}
\hline & $\begin{array}{l}\text { Normal } \\
(n=11)\end{array}$ & $\begin{array}{l}\text { LV } \\
\text { Hypertrophy } \\
(n=8)\end{array}$ & $\begin{array}{l}\text { Confidence } \\
\text { level }\end{array}$ \\
\hline $\begin{array}{l}\text { Body weight }(k g) \\
\text { (mean } \pm \text { SEM) }\end{array}$ & $25 \pm 3$ & $20 \pm 1$ & NS \\
$\begin{array}{l}\text { LV free wall weight }(g) \\
\text { LV free wall weight/ } \\
\text { body weight }(g / k g)\end{array}$ & $81 \pm 9$ & $123 \pm 9$ & $P<0.05$ \\
$\begin{array}{c}\text { LV free wall and } \\
\text { septum weight }(g)\end{array}$ & $110 \pm 11$ & $166 \pm 12$ & $P<0.05$ \\
$\begin{array}{c}\text { LV free wall and } \\
\text { septum weight/body } \\
\text { weight }(g / k g)\end{array}$ & $4.41 \pm 0.19$ & $8.15 \pm 0.53$ & $P<0.01$ \\
$\begin{array}{l}\text { RV free wall weight }(g) \\
\text { RV free wall weight/ } \\
\text { body weight }(g / k g)\end{array}$ & $39 \pm 4$ & $43 \pm 3$ & NS \\
& $1.56 \pm 0.07$ & $2.10 \pm 0.12$ & $P<0.05$
\end{tabular}

NS, not significant.

I). Since there were no differences in morphology, hemodynamic response, and adrenergic receptor number in the sham-operated controls and the normal adult animals, the data were pooled from these two groups and are referred to as the normal control group.

\section{Physiological studies}

Base-line values. Except for LV systolic pressure and LV stroke shortening, base-line values for mean arterial pressure, heart rate, and LV end-diastolic pressure and diameter were similar in the two groups (Tables II and III). In the group of dogs with LV hypertrophy, LV systolic pressure $(250 \mathrm{mmHg})$ was twice $(P<0.01)$ that in the normal control group $(125 \mathrm{mmHg})$, while LV stroke shortening $(5.0 \mathrm{~mm})$ was less, $P<0.01$, in LV hypertrophy than in the normal animals $(8.9 \mathrm{~mm})$.

Responses to norepinephrine. Typical responses to the same dose of norepinephrine, $1.0 \mu \mathrm{g} / \mathrm{kg}$, are shown in a normal dog (Fig. 1) and in a dog with severe LV hypertrophy (Fig. 2). Doseresponse curves for normal dogs and dogs with LV hypertrophy are shown in Table II and illustrated in Fig. 3. In both groups of dogs, increasing doses of norepinephrine (Table II) or isoproterenol (Table III) produced equivalent changes in LV dP/ dt and arterial pressure. The increases in LV systolic pressure were greater in dogs with LV hypertrophy, but base-line values were higher in that group. The only other significant differences were that LV end-systolic diameter fell less at some doses, which was most likely due to the higher LV systolic pressure. With isoproterenol, LV end-diastolic diameter tended to fall more in the normal dogs than in the dogs with LV hypertrophy.

\section{Myocardial $\beta$-adrenergic receptor binding studies}

Saturation plots of $\left[{ }^{3} \mathrm{H}\right] \mathrm{DHA}$ binding demonstrated a significant increase in $\beta$-adrenergic receptor concentration in the membranes prepared from the hypertrophied LV. Specific $\left[{ }^{3} \mathrm{H}\right] \mathrm{DHA}$ 
Table II. Effects of Norepinephrine, $0.05-1.50 \mu \mathrm{g} / \mathrm{kg}$

\begin{tabular}{|c|c|c|c|c|c|c|}
\hline & \multicolumn{6}{|c|}{ Changes \pm SEM from base line at the following doses $(\mu \mathrm{g} / \mathrm{kg})$} \\
\hline & Base line \pm SEM & 0.05 & 0.10 & 0.50 & 1.00 & 1.50 \\
\hline \multicolumn{7}{|c|}{$\begin{array}{l}\text { LV Systolic pressure } \\
\quad(m m H g)\end{array}$} \\
\hline Normal & $126 \pm 3.8$ & $7.7 \pm 2.4$ & $21.4 \pm 6.1$ & $70.0 \pm 7.0$ & $96.2 \pm 12.7$ & $122 \pm 18$ \\
\hline LVH & $249 \pm 24.9^{*}$ & $26.5 \pm 8.0 \dagger$ & $55.0 \pm 11.4 \dagger$ & $156 \pm 35 \dagger$ & $168 \pm 37$ & $184 \pm 30$ \\
\hline \multicolumn{7}{|c|}{$\begin{array}{l}\text { LV End-diastolic pressure } \\
\qquad(\mathrm{mmHg})\end{array}$} \\
\hline Normal & $8.8 \pm 1.1$ & $0.6 \pm 0.4$ & $0.1 \pm 0.6$ & $0.2 \pm 0.9$ & $1.2 \pm 0.6$ & $2.1 \pm 1.7$ \\
\hline LVH & $10.5 \pm 0.9$ & $0.7 \pm 0.3$ & $1.7 \pm 0.2$ & $2.3 \pm 0.3$ & $2.0 \pm 1.2$ & $3.7 \pm 1.4$ \\
\hline \multicolumn{7}{|c|}{$\mathrm{LV} \mathrm{dP} / \mathrm{dt}(m m H g / s)$} \\
\hline Normal & $3,721 \pm 172$ & $805 \pm 308$ & $1,354 \pm 404$ & $4,930 \pm 516$ & $6,650 \pm 196$ & $7,182 \pm 633$ \\
\hline LVH & $3,831 \pm 438$ & $644 \pm 218$ & $1,482 \pm 192$ & $5,736 \pm 628$ & $6,766 \pm 664$ & $7,617 \pm 473$ \\
\hline \multicolumn{7}{|c|}{$\begin{array}{l}\text { LV End-diastolic diameter } \\
\qquad(\mathrm{mm})\end{array}$} \\
\hline Normal & $35.0 \pm 2.5$ & $-0.3 \pm 0.3$ & $0.3 \pm 0.4$ & $0.1 \pm 0.1$ & $0.5 \pm 0.5$ & $-0.2 \pm 0.2$ \\
\hline LVH & $30.0 \pm 2.2$ & $0.5 \pm 0.3$ & $0.5 \pm 0.1$ & $0.4 \pm 0.2$ & $0.3 \pm 0.1$ & $-0.2 \pm 0.5$ \\
\hline \multicolumn{7}{|c|}{$\begin{array}{l}\text { LV End-systolic diameter } \\
\qquad(\mathrm{mm})\end{array}$} \\
\hline Normal & $25.9 \pm 3.0$ & $-0.7 \pm 0.3$ & $-1.1 \pm 0.3$ & $-1.6 \pm 0.4$ & $-1.3 \pm 0.4$ & $-1.7 \pm 0.5$ \\
\hline LVH & $25.0 \pm 2.1$ & $-0.3 \pm 0.1$ & $-0.4 \pm 0.1 \dagger$ & $-0.8 \pm 0.2$ & $-0.6 \pm 0.1$ & $-0.4 \pm 0.1 \dagger$ \\
\hline \multicolumn{7}{|c|}{$\begin{array}{l}\text { LV Stroke shortening } \\
\qquad(\mathrm{mm})\end{array}$} \\
\hline Normal & $9.2 \pm 1.2$ & $0.3 \pm 0.3$ & $1.4 \pm 0.5$ & $1.7 \pm 0.5$ & $1.8 \pm 0.8$ & $1.5 \pm 0.5$ \\
\hline LVH & $4.9 \pm 0.9^{*}$ & $0.8 \pm 0.2$ & $0.8 \pm 0.2$ & $1.1 \pm 0.2$ & $1.0 \pm 0.1$ & $0.2 \pm 0.5$ \\
\hline \multicolumn{7}{|c|}{$\begin{array}{l}\text { Mean arterial pressure } \\
\quad(\mathrm{mmHg})\end{array}$} \\
\hline Normal & $98.3 \pm 3.4$ & $13.7 \pm 4.2$ & $22.4 \pm 4.3$ & $54.0 \pm 8.5$ & $73.0 \pm 11.3$ & $87.3 \pm 8.2$ \\
\hline LVH & $89.0 \pm 4.6$ & $9.2 \pm 3.5$ & $21.3 \pm 6.4$ & $46.7 \pm 3.7$ & $61.0 \pm 4.9$ & $71.8 \pm 10.1$ \\
\hline \multicolumn{7}{|c|}{ Heart rate (beats/min) } \\
\hline Normal & $92.5 \pm 3.3$ & $-13.3 \pm 3.3$ & $-23.8 \pm 5.4$ & $-20.3 \pm 2.5$ & $-19.8 \pm 2.8$ & $-16.2 \pm 4.9$ \\
\hline LVH & $94.2 \pm 5.0$ & $-12.0 \pm 4.8$ & $-14.0 \pm 5.7$ & $-23.0 \pm 3.3$ & $-20.8 \pm 4.3$ & $-20.4 \pm 8.9$ \\
\hline
\end{tabular}

LVH group $(n=6)$ significantly different from control group $(n=6)$.

$* P<0.01$.

$\ddagger P<0.05$.

binding to the myocardial membrane preparation was saturable, yielding a single component, linear Scatchard relationship (7). Typical Scatchard analyses of $\left[{ }^{3} \mathrm{H}\right] \mathrm{DHA}$ binding to normal LV myocardial membranes and LV hypertrophied membrane preparations are shown in Fig. 4. In these experiments, the affinity for $\left[{ }^{3} \mathrm{H}\right] \mathrm{DHA}$ was decreased, $P<0.05$, in the $\mathrm{LV}$ of the hypertrophy $\operatorname{dog}$ (disassociation constant $\left[K_{\mathrm{D}}\right]=10.7 \pm 1.8 \mathrm{nM}$ ), as compared with the normal $L V$ preparation $\left(K_{\mathrm{D}}=6.8 \pm 0.7\right.$ $\mathrm{nM})$. The density of binding sites, as determined from the Scatchard analysis, was significantly higher $(P<0.01)$ in the LV hypertrophy preparation $(n=8)$ as compared with the normal membranes $(n=11)(111 \pm 8.8$ vs. $61 \pm 5.6 \mathrm{fmol} / \mathrm{mg}$ protein $)$ (Fig. 5). The density of binding sites and $K_{\mathrm{D}}$ in the left ventricle of the dogs with LV hypertrophy was significantly greater ( $P$ $<0.01)$ than the RV receptor number $(79.4 \pm 8.4 \mathrm{fmol} / \mathrm{mg}$ protein) and $K_{\mathrm{D}}(5.4 \pm 0.7 \mathrm{nM})$ for the same dogs. It is also important to note that the $\beta$-adrenergic receptor number $(63.2 \pm 7.0 \mathrm{fmol} /$ mg protein) and $K_{\mathrm{D}}(5.4 \pm 0.7 \mathrm{nM})$ in the right ventricles in the normal group were similar to those in the right ventricles of the LV hypertrophy group.

To be sure that the increase in $\beta$-adrenergic receptor density in the LV hypertrophy membranes did not reflect a difference 
Table III. Effects of isoproterenol, 0.01-0.50 $\mu \mathrm{g} / \mathrm{kg}$

\begin{tabular}{|c|c|c|c|c|c|}
\hline & \multicolumn{5}{|c|}{ Changes \pm SEM from base line at the following doses $(\mu \mathrm{g} / \mathrm{kg})$} \\
\hline & Base line \pm SEM & 0.01 & 0.05 & 0.10 & 0.50 \\
\hline \multicolumn{6}{|c|}{ LV Systolic pressure $(\mathrm{mmHg})$} \\
\hline Normal & $123 \pm 6.7$ & $-1.7 \pm 1.7$ & $0.2 \pm 3.3$ & $5.2 \pm 2.3$ & $29.1 \pm 10.5$ \\
\hline LVH & $250 \pm 26^{*}$ & $4.8 \pm 4.8$ & $44.2 \pm 22.9$ & $80.7 \pm 25.8 \dagger$ & $173 \pm 46 \dagger$ \\
\hline \multicolumn{6}{|c|}{ LV End-diastolic pressure $(\mathrm{mmHg})$} \\
\hline Normal & $8.8 \pm 1.2$ & $-2.0 \pm 1.3$ & $-3.3 \pm 1.0$ & $-4.2 \pm 1.3$ & $-4.8 \pm 1.8$ \\
\hline LVH & $9.9 \pm 1.3$ & $0.1 \pm 0.1$ & $-2.0 \pm 0.6$ & $-2.7 \pm 0.4$ & $-4.3 \pm 0.7$ \\
\hline \multicolumn{6}{|c|}{$\mathrm{LV} \mathrm{dP} / \mathrm{dt}(\mathrm{mmHg} / \mathrm{s})$} \\
\hline Normal & $3,565 \pm 167$ & $346 \pm 82$ & $1,325 \pm 289$ & $2,681 \pm 371$ & $5,883 \pm 386$ \\
\hline LVH & $3,819 \pm 395$ & $410 \pm 104$ & $944 \pm 296$ & $2,921 \pm 347$ & $7,687 \pm 742$ \\
\hline \multicolumn{6}{|c|}{ LV End-diastolic diameter $(\mathrm{mm})$} \\
\hline Normal & $34.9 \pm 2.1$ & $-0.5 \pm 0.2$ & $-1.9 \pm 0.5$ & $-3.0 \pm 0.9$ & $-3.5 \pm 1.0$ \\
\hline LVH & $29.7 \pm 2.2$ & $-0.2 \pm 0.2$ & $-0.3 \pm 0.2 \dagger$ & $-1.4 \pm 0.4$ & $-1.4 \pm 0.6 \dagger$ \\
\hline \multicolumn{6}{|c|}{ LV End-systolic diameter ( $\mathrm{mm}$ ) } \\
\hline Normal & $26.6 \pm 2.3$ & $-0.8 \pm 0.4$ & $-2.2 \pm 0.6$ & $-3.1 \pm 0.6$ & $-4.6 \pm 1.3$ \\
\hline LVH & $24.7 \pm 2.2$ & $-0.9 \pm 0.3$ & $-1.3 \pm 0.4$ & $-1.4 \pm 0.4 \dagger$ & $-1.8 \pm 0.7 \dagger$ \\
\hline \multicolumn{6}{|c|}{ LV Stroke shortening $(\mathrm{mm})$} \\
\hline Normal & $8.3 \pm 0.9$ & $0.3 \pm 0.2$ & $0.3 \pm 0.2$ & $0.1 \pm 0.2$ & $1.1 \pm 0.5$ \\
\hline LVH & $5.0 \pm 1.0^{*}$ & $0.7 \pm 0.3$ & $1.0 \pm 0.5$ & $0.1 \pm 0.2$ & $-0.5 \pm 0.6$ \\
\hline \multicolumn{6}{|c|}{ Mean Arterial pressure $(\mathrm{mmHg})$} \\
\hline Normal & $96.5 \pm 4.1$ & $-6.4 \pm 2.6$ & $-20.0 \pm 5.7$ & $-22.0 \pm 3.3$ & $-35.2 \pm 2.1$ \\
\hline LVH & $85.0 \pm 5.3$ & $-10.3 \pm 2.5$ & $-19.7 \pm 3.8$ & $-23.3 \pm 3.5$ & $-32.0 \pm 5.5$ \\
\hline \multicolumn{6}{|c|}{ Heart rate (beats/min) } \\
\hline Normal & $93.3 \pm 1.2$ & $13.7 \pm 1.9$ & $50.2 \pm 13.2$ & $74.2 \pm 18.8$ & $99.7 \pm 16.8$ \\
\hline LVH & $97.3 \pm 6.6$ & $28.5 \pm 11.4$ & $41.3 \pm 10.0$ & $61.2 \pm 13.0$ & $104 \pm 9$ \\
\hline
\end{tabular}

LVH group $(n=6)$ significantly different from control group $(n=6)$.

$* P<0.01$.

$+P<0.05$.

in protein content induced by the preparation of the membranes, they were assayed for their content of another membrane-associated protein uninvolved in receptor ligand binding. The membrane-associated activity of $5^{\prime}$ nucleotidase was higher in normal $(64 \pm 6.6 \mathrm{mIU} / \mathrm{mg}$ protein) $(n=8)$ than in LV hypertrophy preparations $(35 \pm 7.1 \mathrm{mIU} / \mathrm{mg}$ protein $)(n=5)$.

In order to determine if there was an alteration in receptor affinity for agonists in the hypertrophied LV, isoproterenol competition curves were performed with and without $0.1 \mathrm{mM}$ GppNHp. No differences in the $\mathrm{IC}_{50}$ were seen in the left ventricles of control vs. hypertrophied dogs or when compared with the right ventricle. The $\mathrm{IC}_{50}$ for the left ventricles of control animals with isoproterenol and $0.1 \mathrm{mM} \mathrm{GppNHp}$ was $1.0 \pm 0.2$ $\mu \mathrm{M}$, as compared with $0.8 \pm 0.3 \mu \mathrm{M}(n=4)$ without $\mathrm{GppNHp}$. In the left ventricles from hypertrophied animals the $\mathrm{IC}_{50}$ with isoproterenol and $0.1 \mathrm{mM} \mathrm{GppNHp}$ was $1.2 \mu \mathrm{M}$, and without
GppNHp the $\mathrm{IC}_{50}$ was $0.6 \mu \mathrm{M}(n=2)$. At $100 \mu \mathrm{M}$ isoproterenol the specific binding was $60 \%$.

$\beta$-adrenergic receptor-mediated isoproterenol stimulation of adenylate cyclase was examined in the membrane preparations from both normal and LV hypertrophied hearts. As shown in Fig. 6, there were no significant differences in the dose-response curves for isoproterenol-stimulated adenylate cyclase activity in either normal and LV hypertrophied hearts, or in the left or right ventricles from the dogs with $\mathrm{LV}$ hypertrophy. The $\mathrm{EC}_{50}$ in each case was $6 \mu \mathrm{M}$. However, examination of maximalstimulated adenylate cyclase activity did demonstrate differences between normal and hypertrophied left ventricles. For example, $\mathrm{NaF}$ stimulation resulted in adenylate cyclase activity of $5,726 \pm 1,508 \mathrm{pmol} / \mathrm{min}$ per $\mathrm{mg}$ protein in normals, $(n=6)$ compared with $2,014 \pm 491 \mathrm{pmol} / \mathrm{min}$ per $\mathrm{mg}$ protein in $\mathrm{LV}$ hypertrophy $(n=6)$. With GppNHp $1 \mathrm{mM}$, the maximal ad- 


\section{LV Pressure $(\mathbf{m m H g})$}

LV $\mathrm{dP} / \mathrm{dt}$ $(\mathbf{m m H g} / \mathbf{s})$

\section{LV \\ Diameter $(\mathbf{m m})$}

\section{Mean Arterial Pressure $(\mathrm{mmHg})$}

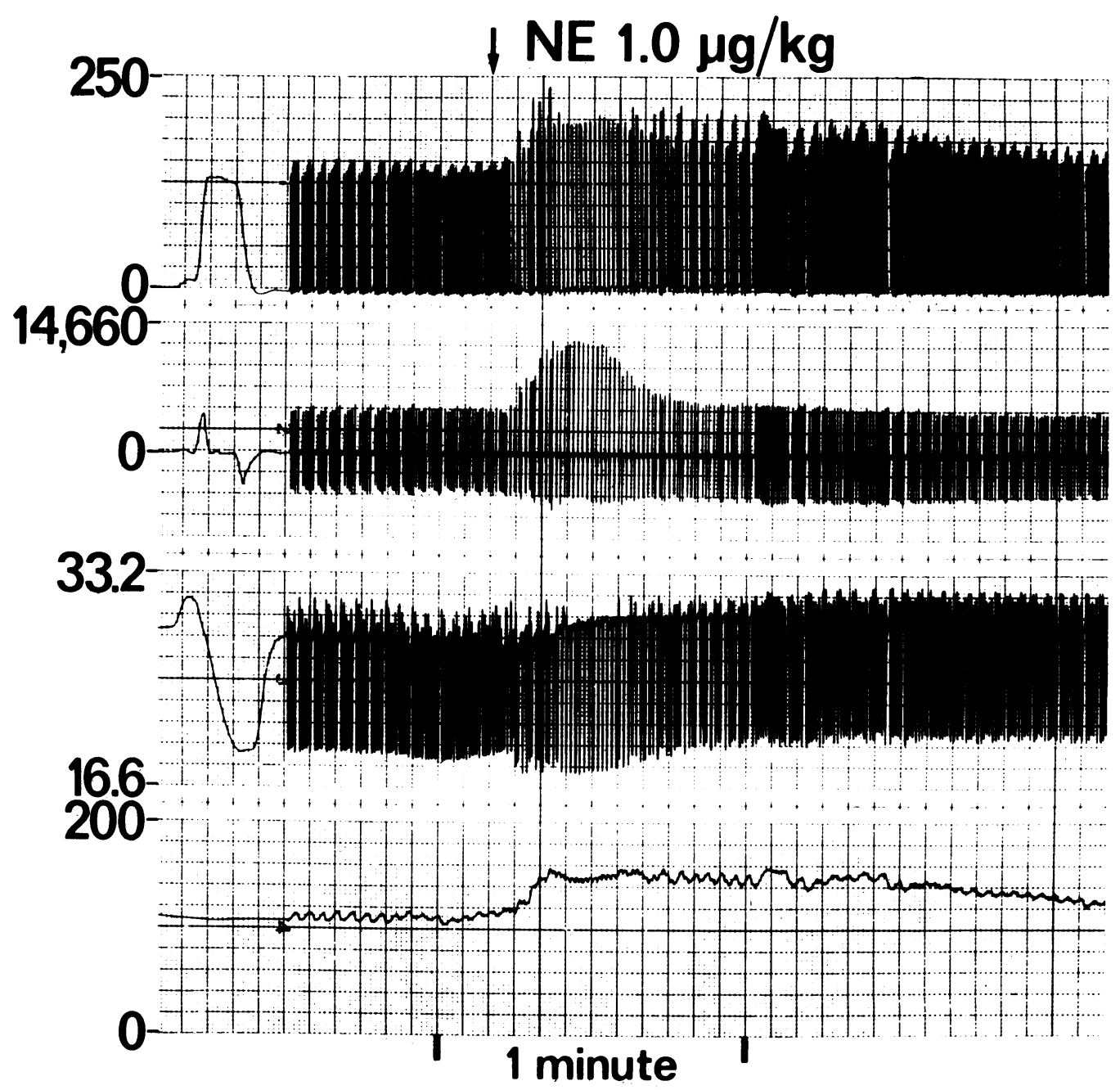

Figure 1. The effects of a bolus of norepinephrine $(1.0 \mu \mathrm{g} / \mathrm{kg})$ are shown on phasic measurements of $\mathrm{LV}$ pressure, $\mathrm{LV} \mathrm{dP} / \mathrm{dt}, \mathrm{LV}$ diameter, and mean arterial pressure in a normal dog.

enylate cyclase stimulation for the normal left ventricle was $1,628 \pm 345 \mathrm{pmol} / \mathrm{min}$ per $\mathrm{mg}$ protein as compared with $599 \pm 238$ $\mathrm{pmol} / \mathrm{min} / \mathrm{per} \mathrm{mg}$ protein for hypertrophied left ventricles, $P$ $<0.05$.

\section{Myocardial and plasma catecholamines}

LV norepinephrine was higher, $P<0.01$, in the normal control group $(835 \pm 166 \mathrm{pg} / \mathrm{mg})$ than in the group with LV hypertrophy $(163 \pm 48 \mathrm{pg} / \mathrm{mg})$. Plasma norepinephrine and epinephrine were similar in dogs with LV hypertrophy $(223 \pm 26$ and $81 \pm 13 \mathrm{pg} /$ $\mathrm{ml})$ as compared with normal controls $(251 \pm 23$, and $122 \pm 17$ $\mathrm{pg} / \mathrm{ml})$.

\section{Discussion}

Base-line hemodynamics were remarkably similar in the normal dogs and dogs with LV hypertrophy. Only LV systolic pressure was significantly elevated, and LV stroke shortening was reduced in the dogs with hypertrophy. The dogs with LV hypertrophy appeared fully compensated in terms of normal daily activities and with respect to hemodynamics, particularly in the normal values for LV end-diastolic pressure and LV end-diastolic diameter and LV dP/dt. Specifically, the ventricles, while hypertrophied, were not dilated and did not exhibit any reduction in LV peak dP/dt. Moreover, when the ventricles were stressed with norepinephrine in increasing bolus doses, the responses of the normal and LV hypertrophy hearts, particularly with respect to $\mathrm{LV} \mathrm{dP/dt,} \mathrm{were} \mathrm{almost} \mathrm{superimposable} \mathrm{(Fig.} \mathrm{3).} \mathrm{In} \mathrm{fact,} \mathrm{the}$ hypertrophied hearts were able to generate even greater pressure, in some instances up to $600 \mathrm{mmHg}$ (Fig. 2), without failing. This finding of similar inotropic response in normal and pressure overload LV hypertrophy differs from studies in anesthetized dogs with pressure overload LV hypertrophy, which showed a depressed length-contractile force curve in response to isopro- 


\section{LV Pressure $(\mathbf{m m H g})$

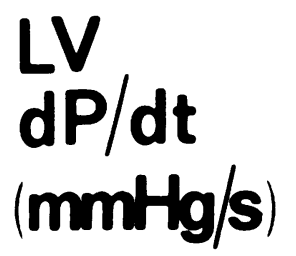

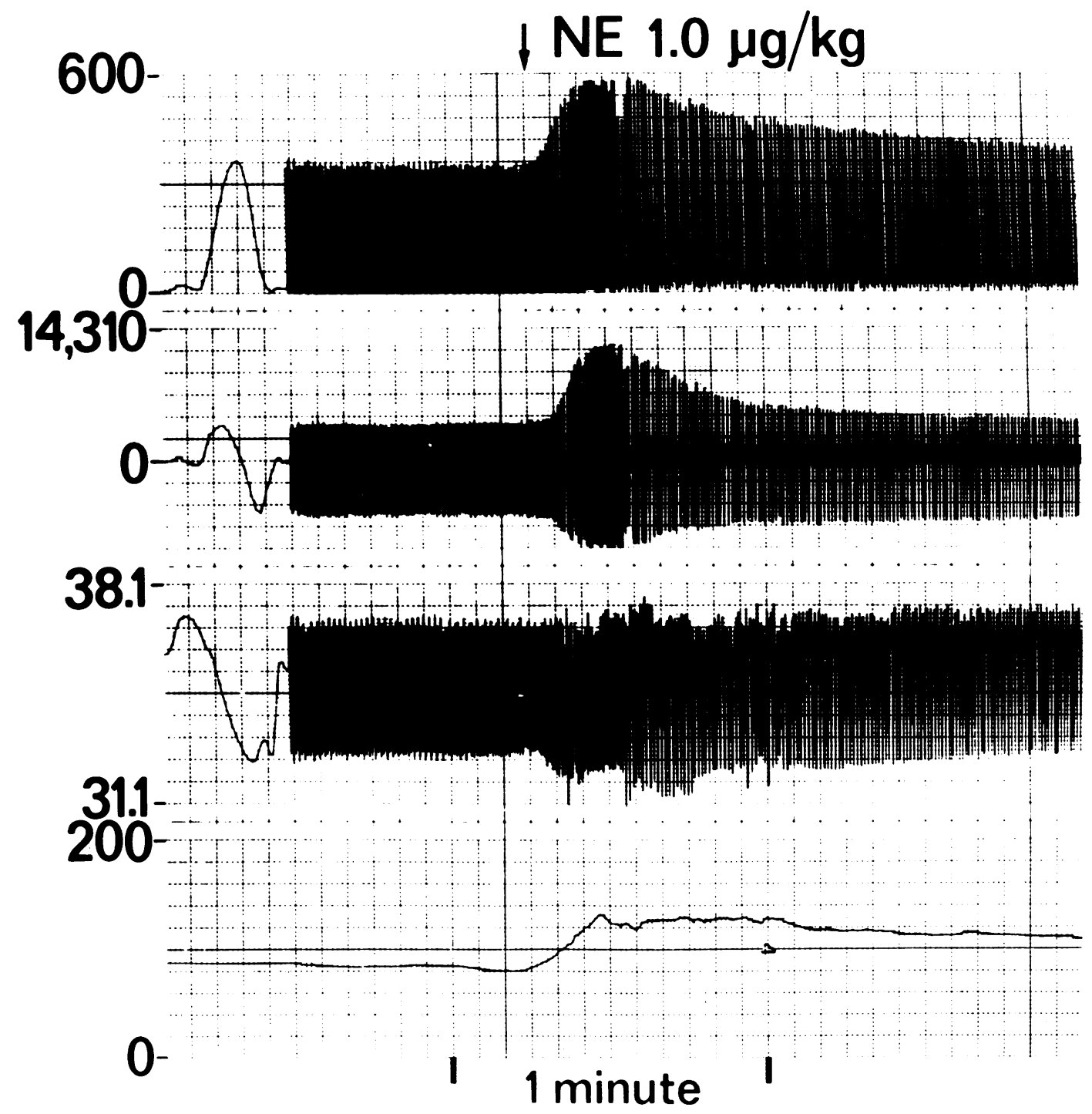

Figure 2. The effects of a bolus of norepinephrine $(1.0 \mu \mathrm{g} / \mathrm{kg})$ are shown on phasic measurements of LV pressure, LV dP/dt, LV diameter, and mean arterial pressure in the dog with pressure overload LV hypertrophy. The response of $\mathrm{LV} \mathrm{dP/dt}$ was nearly identical to that

observed in the normal animal (Fig. 1). In this animal, this dose of norepinephrine increased LV systolic pressure to nearly $600 \mathrm{~mm} \mathrm{Hg}$ without inducing LV decompensation.

terenol (10). Also, in rats with renovascular hypertension and LV hypertrophy, the inotropic response to isoproterenol, as measured by LV dP/dt, was depressed from those observed in normal hearts (11). It is possible that the depressed inotropic response in previous studies $(10,11)$ is secondary to the use of general anesthesia or the open chest preparation.

Despite the maintenance of normal physiologic responsiveness to catecholamines in the hypertrophied myocardium, direct characterization of $\beta$-adrenergic receptor number and affinity revealed definite differences. An unexpected finding in this study was the decreased $\beta$-adrenergic receptor affinity that was consistently observed in the membranes from the hypertrophied

left ventricle. One explanation may be that a different form of the receptor is expressed during the development of LV hypertrophy. Such receptor microheterogeneity might explain the altered affinity and may be compared with the shift in isozyme patterns seen in other proteins in cardiac hypertrophy, which include: $(a)$ the shift towards the $\mathrm{V}_{3}$ isozyme of the myosin heavy chain in the rat with aortic banding (12), (b) the marked increase in MB-creatine kinase in the dog myocardium with pressure overload hypertrophy (13), and (c) the increase in the anerobic M-type isozyme of $\mathrm{LDH}$ in the heart with pressure overload hypertrophy (14-16). These proteins appear to change towards a more developmentally immature type of isozyme. 


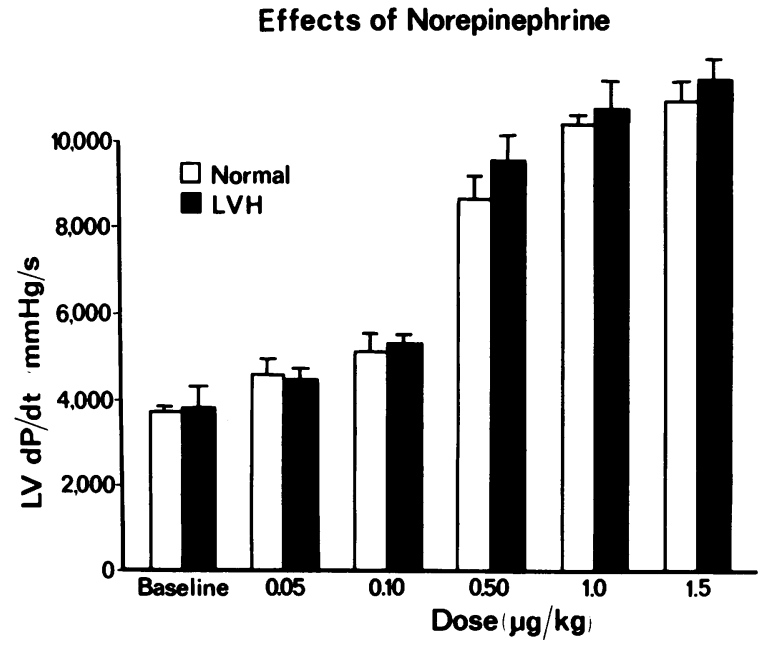

Figure 3. The peak $\mathrm{LV} \mathrm{dP/dt} \mathrm{levels} \mathrm{achieved} \mathrm{by} \mathrm{increasing} \mathrm{doses} \mathrm{of}$ norepinephrine are compared in normal $(n=6)$ and LV hypertrophied $\operatorname{dogs}(n=6)$ on $\mathrm{LV} \mathrm{dP} / \mathrm{dt}(\mathrm{mmHg} / \mathrm{s})$. There were no differences in the responses of peak $\mathrm{LV} \mathrm{dP/dt}$ to norepinephrine in the two groups.

The future development of methods that permit both purification $(17,18)$ and photoaffinity labeling of the hormone-binding subunit (17-20) will permit this hypothesis to be examined at the molecular level.

The decrease in $\beta$-adrenergic receptor affinity in the presence of chronic pressure overload LV hypertrophy may be offset by the increase in receptor number, which results in the normal inotropic response of the LV hypertrophied ventricle to catecholamines. These changes in receptor number and affinity were unique to the left ventricles from the dogs with LV hypertrophy, since they were not observed in the normal dogs and were not observed in the right ventricles from the dogs with LV hypertrophy.

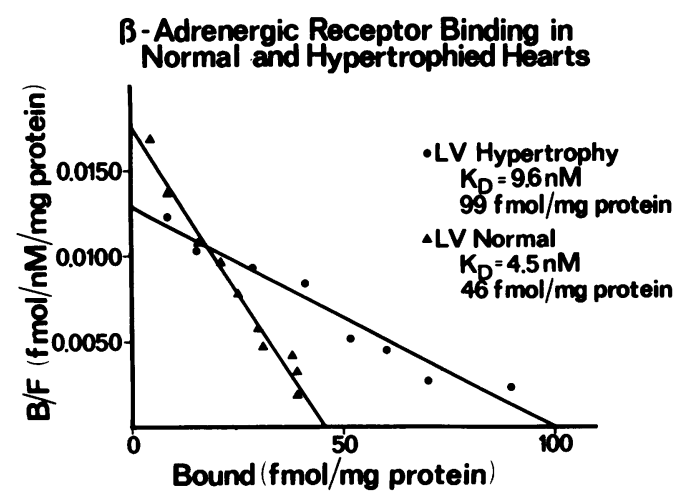

Figure 4. Scatchard analyses of $\beta$-adrenergic receptor binding are compared in the normal (triangles) and hypertrophied (circles) LV plasma membranes. The LV hypertrophied heart shows a lower affinity and more receptors per milligram protein than the normal LV.

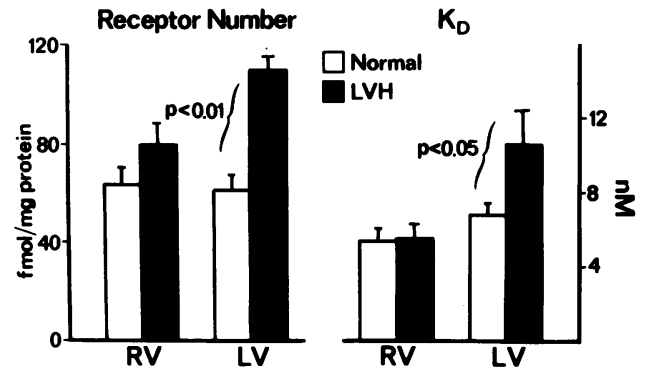

Figure 5. $\beta$-adrenergic receptor concentration and affinity constants $\left(K_{\mathrm{D}}\right)$ are compared in the right and left ventricles of normal dogs $(n$ $=11)$ and dogs with LV hypertrophy $(n=8)$. Note that the marked increases in both receptor number and $K_{\mathrm{D}}$ are only observed in the LV of dogs with LV hypertrophy.

Our finding of a significant increase $(P<0.01)$ in receptor density in the hypertrophied left ventricle as compared with the normal left ventricle differs from the majority of prior work conducted in this field. Most prior studies were conducted in rodents with either renovascular hypertension $(21-24)$ or in SHR rat models $(25,26)$. In these studies, $\beta$-adrenergic receptor number was either normal $(24,26)$ or depressed $(21-24)$, with normal affinity. These differences could be due to different species or to the model. Favoring the latter is the finding of Limas (27), with aortic banded rats, showing increased $\beta$-adrenergic receptor number. In contrast, a study by Cervoni et al. (28) demonstrated no changes in $\beta$-adrenergic receptor number or in affinity in rats with aortic banding. In addition, Kumano et al. found an increase in $\beta$-adrenergic receptor density and no change in $K_{\mathrm{D}}$ in the renal hypertensive rat, and found a decreased receptor density in the SHR rat with no change in affinity (29). Another consideration is the presence or absence of congestive failure. Karliner et al. (30) found increased $\beta$-adrenergic receptor number and no change in affinity in guinea pigs with experimental congestive heart failure, whereas Bristow et al. (31) found significantly reduced $\beta$-adrenergic receptor number and no change in $K_{\mathrm{D}}$ in failing human hearts. Other important differences in experimental design include the severity of the hypertrophy in the dogs in the present study where LV weight per body weight rose by $87 \%$ compared with results in prior studies in rodents $(21,23,28)$, where LV per body weight increased $20-50 \%$. In

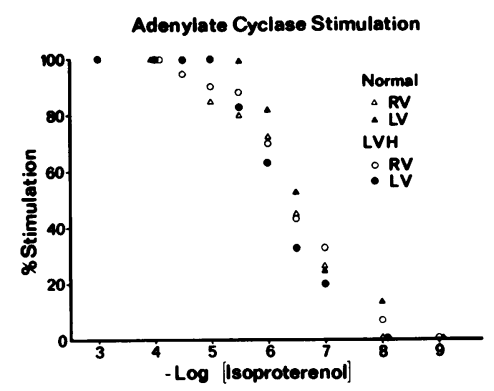

Figure 6. This graph of adenylate cyclase stimulation with isoproterenol compares the RV and LV of normal $(n=6)$ and hypertrophied hearts $(n=6)$ and shows no significant differences. 
these animals, the receptor number decreased without any change in affinity. Thus, the severity of hypertrophy is another factor to be considered.

The increased number of receptors found in the membrane preparations in the dogs with LV hypertrophy could not be attributed to a difference in the membrane preparations. Another membrane marker, $5^{\prime}$ nucleotidase, was found to be significantly depressed in the membrane preparation from the animals with LV hypertrophy. A second sarcolemmal marker, maximal-stimulatable adenylate cyclase was also lower in the hypertrophied $\mathrm{LV}$, whether it was determined in the presence of $\mathrm{NaF}$ or GppNHp, at maximally effective concentrations. One can only speculate on the reasons for the decreased maximal adenylate cyclase activity in these preparations. In view of the observed decrease in two sarcolemmal markers, however, $5^{\prime}$ nucleotidase and adenylate cyclase, it is possible that the membrane preparation from the hypertrophied LV was contaminated with nonplasma membrane proteins, as might occur if fibrosis or increased collagen deposition had occurred during the development of LV hypertrophy. These data imply that the observed increase in $\beta$-receptor density in the hypertrophied myocardium, the major goal and finding of the present investigation, may have been an underestimation.

Other problems due to the method of raising the puppies to adulthood or due to the operation at an early age were considered. To rule out that these possibilities accounted for the differences, sham-operated litter mates, indistinguishable in terms of $\beta$-adrenergic receptor number or affinity from the other normal, mongrel adult control animals, were studied. However, it is still conceivable that a pressure-overload stimulus applied at a young age results in a different response in terms of $\beta$ adrenergic receptor response than when the stimulus is applied to the adult.

While plasma levels of both epinephrine and norepinephrine were similar in the two groups, it is also conceivable that the increased $\beta$-adrenergic receptor number represents "upregulation" secondary to the depleted catecholamine stores of the hypertrophied left ventricle. This phenomenon of reduced tissue norepinephrine levels has been a consistent feature of cardiac failure (32).

In the normal dogs and dogs with LV hypertrophy, although the maximally stimulatable adenylate cyclase differed, the doseresponse curves for adenylate cyclase stimulation by isoproterenol were similar. A small decrease in the $\mathrm{EC}_{50}$ for adenylate cyclase stimulation secondary to an increase in receptor number would have been difficult to detect, particularly in the setting of the decreased affinity in this preparation. It is postulated that the increased $\beta$-adrenergic receptor number may be an important control mechanism compensating for the reduced adrenergic innervation (decreased tissue norepinephrine levels) and the decreased affinity of the $\beta$-adrenergic receptor in the hypertrophied myocardium. It should also be apparent that the hemodynamic and cellular profiles observed with hypertrophy may differ depending upon $(a)$ species, e.g., rat vs. large mammal and man; $(b)$ inducing stimulus, pressure vs. volume overload, mechanical pressure overload vs. systemic hypertension; $(c)$ whether the stimulus is applied to the immature or adult animal; $(d)$ severity of the stimulus; ( $e$ ) the duration of the stimulus; $(f)$ the chamber involved; and $(g)$ the presence or absence of cardiac failure.

\section{Acknowledgments}

We would like to thank M. Connole for her meticulous performance of the adenylate cyclase and catecholamine assays. We are also grateful for the guidance provided by Dr. Robert Graham in establishing the iterative computer analysis of the data.

This work was supported in part by U. S. Public Health Service grants Nos. HL 23724, 15416, 19259, and 31280, and by MA Heart Assoc. grant 13-530-823.

\section{References}

1. Patrick, T. A., S. F. Vatner, W. S. Kemper, and D. Franklin. 1974. Telemetry of left ventricular diameter and pressure measurements from unrestrained animals. J. Appl. Physiol. 37:276-281.

2. Pagani, M., S. F. Vatner, H. Baig, D. L. Franklin, T. Patrick, W. T. Manders, P. Quinn, and A. Sherman. 1978. Measurement of multiple simultaneous small dimensions and study of arterial pressuredimension relations in conscious animals. Am. J. Physiol. 4:H610-H617.

3. Homcy, C., S. Wrenn, and E. Haber. 1977. Demonstration of the hydrophilic character of adenylate cyclase following hydrophobic resolution on immobilized alkyl residues: critical role of alkyl chain length. J. Biol. Chem. 252:8957-8964.

4. Arkesteijn, C. L. M. 1976. A kinetic method for serum $5^{\prime}$ nucleotidase using stabilized glutamate dehydrogenase. J. Clin. Chem. Clin. Biochem. 14:155-158.

5. DaPrada, M., and G. Zurcher. 1976. Simultaneous radioenzymatic determination of plasma and tissue adrenaline, noradrenaline, and dopamine within the femtomole range. Life Sci. 19:1161-1174.

6. Lowry, O. H., N. J. Rosebrough, A. L. Farr, and R. J. Randall. 1951. Protein measurement with folin phenol reagent. J. Biol. Chem. 193:265-275.

7. Scatchard, G. 1949. The attractions of proteins for small molecules and ions. Ann. NY Acad Sci. 51:660-672.

8. Munson, P. J., and D. Rodbard. 1982. Ligand: a versatile computerized approach for characterization of ligand-binding systems. Anal. Biochem. 107:220-239.

9. Armitage, P. 1975. Statistical Methods in Medical Research. Blackwell Scientific Press, London. 504.

10. Newman, W. H., and J. G. Webb. 1980. Adaptation of left ventricle to chronic pressure overload. Response to inotropic drugs. $\mathrm{Am}$. J. Physiol. 238:H134-H143.

11. Saragoca, M. A., and R. C. Tarazi. 1981. Left ventricular hypertrophy in rats with renovascular hypertension: alterations in cardiac function and adrenergic responses. Hypertension. 3(Suppl II):II-171-II176.

12. Lompre, A., D. Schwartz, A. D'Albis, G. Lacombe, N. Van Thien, and B. Swynghedauw. 1979. Myosin isoenzyme redistribution in chronic heart overload. Nature (Lond.) 282:105-107.

13. Vatner, D. E., S. F. Vatner, S. P. Sit, and J. S. Ingwall. 1982. Alteration of creatine kinase and its isozymes in response to pressure overload. Physiologist. 25:191. 
14. Bishop, S. P., and R. A. Altschuld. 1970. Increased glycolytic metabolism in cardiac hypertrophy and congestive heart failure. Am. J. Physiol. 218:153-159.

15. Sobel, B. E., P. H. Henry, B. J. Ehrlich, and C. M. Bloor. 1970. Altered myocardial lactic dehydrogenase isoenzymes in experimental cardiac hypertrophy. Lab. Invest. 22:23-27.

16. Fox, A. C., and G. E. Reed. 1969. Changes in lactate dehydrogenase composition of hearts with right ventricular hypertrophy. Am. J. Physiol. 216:1026-1033.

17. Homcy, C. J., S. G. Rockson, J. Countaway, and D. A. Egan. 1983. Purification and characterization of the mammalian $\beta_{2}$-adrenergic receptor. Biochemistry. 22:660-668.

18. Shorr, R. G., M. W. Strohsacker, T. N. Lavin, R. J. Lefkowitz, and M. G. Caron. 1982. The $\beta_{1}$-adrenergic receptor of the turkey erythrocyte. Molecular heterogenity revealed by purification and photoaffinity labeling. J. Biol. Chem. 257:12341-12350.

19. Rashidbaigi, A., and A. E. Ruoho. 1981. Iodoazidobenzylpindolol, a photoaffinity probe for the $\beta$-adrenergic receptor. Proc. Natl. Acad. Sci. USA. 78:1609-1613.

20. Lavin, T. N., P. Nambi, S. L. Heald, P. W. Jeffs, R. J. Lefkowitz and M. G. Caron. 1982. ${ }^{125}$ I-labeled p-azidobenzylcarazolol, a photoaffinity label for the $\beta$-adrenergic receptor. Characterization of the ligand and photoaffinity labeling of $\beta_{1}$ - and $\beta_{2}$-adrenergic receptors. $J$ Biol. Chem. 257:12332-12340.

21. Bobik, A., and P. Korner. 1981. Cardiac beta adrenoceptors and adenylate cyclase in normotensive and renal hypertensive rabbits during changes in autonomic activity. Clin. Exp. Hypertens. 3:257-280.

22. Ayobe, M. H., and R. C. Tarazi. 1983. Beta-receptors and contractile reserve in left ventricular hypertrophy. Hypertension. 5(Suppl I):I-192-I-197.

23. Woodcock, E. A., and C. I. Johnston. 1980. Changes in tissue alpha- and beta-adrenergic receptors in renal hypertension in the rat. Hypertension. 2:156-161.
24. Giachetti, A., T. L. Clark, and F. Berti. 1979. Subsensitivity of cardiac $\beta$-adrenoceptors in renal hypertensive rats. J. Cardiovas. Pharmacol. 1:467-471.

25. Limas, C., and C. J. Limas. 1978. Reduced number of $\beta$-adrenergic receptors in the myocardium of spontaneously hypertensive rats. Biochem. Biophys. Res. Commun. 83:710-714.

26. Mukherjee, A., R. M. Graham, A. I. Sagalowsky, W. Pettinger, and K. E. McCoy. 1980. Myocardial beta-adrenergic receptors in the stroke-prone spontaneously hypertensive rat. J. Mol. Cell Cardiol. 12:1263-1272.

27. Limas, C. J. 1979. Increased number of $\beta$-adrenergic receptors in the hypertrophied myocardium. Biochim. Biophys. Acta. 588:174178.

28. Cervoni, P., H. Herzlinger, F. M. Lai, and T. Tanikella. 1981. A comparison of cardiac reactivity and $\beta$-adrenoceptor number and affinity between aorta-coarcted hypertensive and normotensive rats. $\mathrm{Br}$ J. Pharmacol. 74:517-523.

29. Kumano, K., M. E. Upsher, and P. A. Khairallah. 1983. Beta adrenergic receptor response coupling in hypertrophied hearts. Hypertension. 5(Suppl I):I-175-I-183.

30. Karliner, J. S., P. Barnes, M. Brown, and C. Dollery. 1980. Chronic heart failure in the guinea pig increases cardiac $\alpha_{1}$ - and $\beta$ adrenoceptors. Eur. J. Pharmacol. 67:115-118.

31. Bristow, M. R., R. Ginsburg, W. Minobe, R. S. Cubicciotti, W. S. Sageman, K. Lurie, M. E. Billingham, D. C. Harrison, and E. B. Stinson. 1982. Decreased catecholamine sensitivity and $\beta$-adrenergicreceptor density in failing human hearts. $N$. Engl. J. Med. 307:205211.

32. Spann, J. F., Jr., C. A. Chidsey, P. E. Pool, and E. Braunwald. 1965. Mechanisms of norepinephrine depletion in experimental heart failure produced by aortic constriction in the guinea pig. Circ. Res. 17:312-321. 